\title{
The Implementation of Blended Learning in Multimedia Courses for Undergraduate Students in Indonesia
}

\author{
Herman Dwi Surjono, Ali Muhtadi, and Dian Wahyuningsih
}

\begin{abstract}
This quasi-experimental study investigated the effects of blended and traditional learning in multimedia courses for undergraduate students in Indonesia. The blended group $(N=41)$ was taught using a combination of lectures and online activities, while the control group $(N=41)$ experienced a face-to-face lesson. Both groups received the same multimedia materials during four-week sessions. The findings showed that students learning in blended mode achieved better scores than their counterparts. They also participated in discussion sessions more actively. This study also revealed that in Multimedia courses student achievement has a positive correlation with student activities. Students perceived that the implementation of this blended learning was good.
\end{abstract}

Index Terms-Blended learning, multimedia, e-learning, face-to-face learning.

\section{INTRODUCTION}

The rapid development of information technology encourages educational institutions to run distance education system. Since it was adopted two centuries ago, the system has changed significantly in terms of learning process, communication between teachers and students as well as delivery of teaching materials to students [1]. The system was developed through several stages in accordance with technological developments. In the early stages, communication and distribution of teaching materials to students was done through postal delivery technology, radio and television broadcasts. Today the Internet is becoming a dominant technology to support the system as communication media, shipping materials, and variety of online activities.

E-learning is now becoming the backbone of the distance education in the world. The term of e-learning that refers to learning through the Internet is now becoming popular. E-learning is also referred to as distance education, online learning, virtual learning, distance learning, web-based learning [2]. The use of e-learning in higher education is not exclusively separated with face-to-face learning, but both are used together to obtain optimal learning.

E-learning is the use of information technology to deliver learning materials to anybody, anytime, and anywhere in a

Manuscript received August 12, 2016; received November 16, 2016. This work was supported in part by the Graduate School of Yogyakarta State University, Indonesia.

H. D. Surjono is with the Information Technology Education Department, College of Engineering, Yogyakarta State University, Yogyakarta, Indonesia (e-mail: hermansurjono@uny.ac.id).

A. Muhtadi and D. Wahyuningsih are with Instructional Technology Department of Yogyakarta State University, Yogyakarta, Indonesia (e-mail: alimuhtadi@uny.ac.id,dian@uny.ac.id) learning environment that is open, flexible, and distributed [3]. Urdan \& Weggen [4] mentioned that e-learning is part of distance education, while online learning is part of the e-learning. In addition, e-learning includes a wide range of applications and processes such as computer-based learning, web-based learning, virtual classrooms, etc. More specifically, Rosenberg [5] defines e-learning as the use of internet technology to distribute learning materials, so that students can access from anywhere.

E-learning system can be implemented asynchronously, synchronously, or a mixture of both. Examples of asynchronous e-learning are often found in the Internet whether simple or integrated via e-learning portal. While in the synchronous e-learning, teachers and learners should be in front of computers together because the learning process is conducted in real-time using video or audio conferencing. Hereinafter known as blended learning is learning that combines all forms of learning activity, for example on-line, live, as well as face-to-face (conventional).

A combination of online learning with face-to-face learning is called blended learning [6]. Blended learning is learning that combines the best aspects of face-to-face learning with the excellence of online learning [7] and is predicted to become a model of learning in the future [8], [9]. Blended learning is recognized as a trend in instruction strategy that benefits students because of the mixture of the advantages derived through online and face-to-face activities [10] and would have a great role in the future [11].

Some weaknesses found in face-to-face instruction include limitations of teacher student interaction, delayed feedback, and limited visualization of teaching materials [12]. While the advantages are that students gain hands-on experience and character education to promote good behaviours such as respect, honesty, kindness, and hard work which are modelled by lecturers. Online learning can overcome the limitations of time, location, and culture. Therefore, blended learning provides a new approach that inherits the advantages of each mode of learning [13]-[15].

Kaur [16] classifies blended learning into several different perspectives such as holistic perspective, educational perspective, and pragmatic perspective. In terms of educational perspectives, blended learning is a combination of online learning and face-to-face learning using instructional design. Some parts of classroom lectures are substituted by online activities. This perspective focused on integrating synchronous and asynchronous mode of delivery [17].

Studies about the implementation of blended learning indicated that students who participated in a combination of both online and face-to-face instruction obtained the same or better achievement compared to those of traditional 
instruction [18], [19]. The blended learning environment also encouraged student to be more actively involved in teaching-learning process [20]-[22]. The use of multimedia to promote online learning environment also provides student a better understanding of learning materials [23].

Other studies reported that learning effectiveness in terms of achievement, satisfaction, behaviour, critical thinking skills, learner support, participation, interaction, and retention are similar or better than those of traditional face-to-face learning [19], [24]-[26]. Some studies about blended learning have been conducted and it tends to be "useful, enjoyable, supportive, flexible and motivator for learners" [27]. However, he suggested that in order to obtain more conducive teaching-learning environment, teachers should encourage students to participate actively in online activities.

This study aims to investigate whether student's achievement and participation in blended learning is better than those in face-to-face learning and to determine whether there is a positive correlation between the student's participation and their achievement. We also want to understand student perceptions of experiencing blended learning.

\section{METHODS}

\section{A. Design of the Study}

In this study, an experiment and a control group of quasi-experimental design was used. A blended course covering multimedia-based learning was developed. The independent variable of the study was the learning mode (blended course - face-to-face course); the dependent variables were student's achievement and level of participation. Pre-test and post-test were used to measure the student's achievement before and after the experimentation.

\section{B. Participants}

Study participants consisted of 82 undergraduate students enrolled in "Multimedia-Based Learning" course in the Department of Information Technology Education at the College of Engineering Yogyakarta State University Indonesia. There were 41 students in the control group and 41 students in the experiment group. They participated voluntarily in the study. Prior to group assignments, participants were briefed on the purpose of the study, the experimental group to which they were entered, the learning strategy and subject matter that they would be taught, and their study obligations.

\section{The Blended Course}

For the purpose of this experiment the "Multimedia-based Learning" course was developed in a blended course format in which the online and face-to-face instructions were combined. The course contained learning materials of multimedia, online activities, online quizzes and assignments. The online activities included discussion forum and chatting that were done outside of the face-to-face time. The online quizzes included multiple-choice questions and the assignment included essay questions.

The online component was delivered using an asynchronous learning management system called Besmart (http://besmart.uny.ac.id/v2). The Moodle-based Besmart included course description, course schedule, instructor profile, learning materials (handouts, textbooks, papers, slides, videos, links), announcements, discussion forums, quizzes, and assignments. The course duration was 5 weeks and the students met for face-to-face lecture in addition to the online activities. Students in the control groups received the same learning materials of multimedia through 100-minute face-to-face instruction each week.

\section{Data Collection and Analysis}

To measure the student's achievement, a pre-test and a post-test was provided at the beginning and at the end of the course for both the control and the experiment groups. In addition, during the experimentation, students in both groups took assignments to evaluate the student's level of knowledge about the subject matter. To measure the level of student's participation, a checklist for activity observation was used in the blended and face-to-face groups. To reveal the student's perceptions towards the blended learning, a Likert-scale questionnaire was used.

To investigate the effectiveness of the blended learning in terms of student's achievement and level of student's participation, a t-test analysis for independent samples was conducted. To investigate the correlation between the student's achievement and level of student's participation, a Spearman-rho analysis was conducted. Prior to hypotheses testing, normality and homogeneity of variance were verified by Shapiro-Wilk and Levene's Test respectively.

\section{RESUlTS AND DISCUSSION}

Results of the data analysis are described in Table I. It was found that students in the experiment group obtained higher scores both for post-pre test and assignments than their counterpart in the control group. The mean score of the difference between post-test and pre-test in the experimental group is 3.12 , while in the control group it is 2.00 . The experimental students obtained 7.41 for the assignments and their counterpart achieved 6.57. In addition, their level of participation is also higher.

From the data collected there is a strong evidence to suggest that the student's achievement in the experimental group was better significantly than in the control group with a significance level of 5\% as illustrated in Fig. 1.

In addition, using Mann-Whitney $U$ test, it was found that students in the experiment group were more active in the participation rates than in the control group.

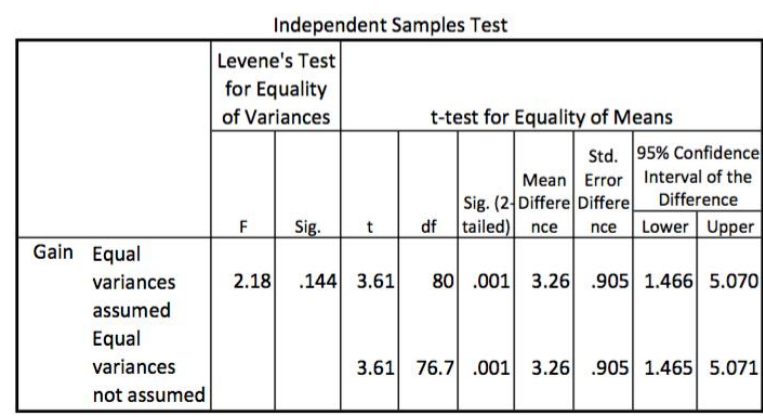

Fig. 1. A t-test summary for student's achievement. 
TABLE I: DESCRIPTIVE STATISTICS OF THE CONTROL AND EXPERIMENT GROUPS

\begin{tabular}{lcccccc}
\hline Group type & $\mathrm{N}$ & Post-Pre Mean & Post-Pre Std. Dev. & Assigment Mean & Assigment Std. & Activity Mean \\
& & & & & Activity Std. Dev. \\
& & & & & \\
\hline Control & 41 & 2.00 & 2.20 & 6.57 & 1.57 & 0.29 \\
Experiment & 41 & 3.12 & 2.10 & 7.41 & 1.79 & 0.51 \\
\hline
\end{tabular}

In terms of correlation between the student's achievement and the student's participation, it was found that a moderate positive correlation happened between those variables as illustrated in Fig. 2. In this study, student's participations in the online activities were identified through their login histories, numbers of messages posted in forums, and numbers of files and pages accessed. Even though student's tracking on the online activities may have been not so accurate, this result supports other studies which state that student interaction plays an important role in success of learning.

Correlations

\begin{tabular}{|lll|r|r|}
\hline & & assr123 & \multicolumn{1}{c|}{ fo123 } \\
\hline Spearman's rho & assr123 & Correlation Coefficient & 1.000 & $.411^{\text {** }}$ \\
& & Sig. (2-tailed) &. & .000 \\
& & 82 & 82 \\
\cline { 2 - 5 } & $\mathrm{N}$ & $.411^{* *}$ & 1.000 \\
& fo123 & Correlation Coefficient & .000 &. \\
& Sig. (2-tailed) & 82 & 82 \\
\hline
\end{tabular}

**. Correlation is significant at the 0.01 level (2-tailed)

Fig. 2. A Spearman's rho summary for student's activity.

A scale of students' views on the blended learning implementation was developed. The instrument which was on a five-point Likert scale consists of 20 expressions with five alternative responses as follows: 1) strongly disagree, 2) disagree, 3) neutral, 4) agree, and 5) strongly agree. These questionnaires aimed to quantitatively determine the views of students on the blended learning and its implementation. The twenty statements are as follows.

1) Blended learning strategy can increase student's motivation.

2) Blended learning strategy can increase interest in learning.

3) Blended learning strategy can optimize learning activity.

4) Blended learning strategy can increase understanding of learning materials.

5) Blended learning strategy can encourage students to think critically.

6) Blended learning strategy can encourage students to express opinions.

7) Student can learn anywhere and anytime through blended learning.

8) Blended learning strategy supports face-to-face learning.

9) Face-to-face activities in blended learning can enhance the role and involvement of students.

10) Online activities in blended learning can enhance the role and involvement of students.

11) Students can easily access the learning materials through blended learning.

12) Students can easily interact with teachers in face-to-face learning.

13) Students can easily interact with teachers in online learning.

14) Students can access diverse of resources in blended learning.

15) Learning materials was presented with a clear organization.

16) Learning activities was carried out with a clear sequence.

17) Evaluation was conducted in face-to-face and online settings.

18) E-learning system was used in blended learning.

19) Implementation of blended learning strategy makes increasingly heavy burden of student learning.

20) Blended learning strategy can be applied to other subjects.

The total scores for each item pertaining to the students' views on the blended learning and its implementation are presented in Fig. 3. The average value is 141.9, which falls in a category of good. One item (number 11) was responded very good and the rest items were good. Therefore, it would be appropriate to mention that the students have a positive attitude towards the blended learning and its implementation.

Scores of Student Responses ( $N=40$ )

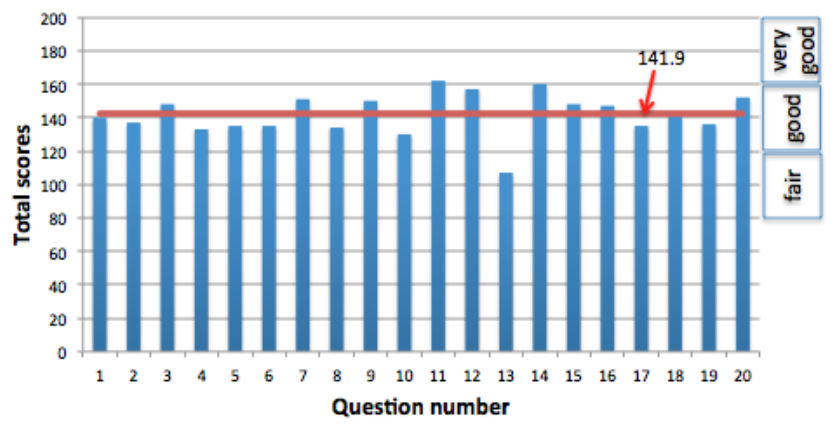

Fig. 3. Scores of student's responses with $\mathrm{N}=40$.

This research is a preliminary effort to investigate student's achievements and student's activities between the blended learning and traditional face-to-face learning. Findings indicated that students who attended the blended instruction had higher achievement scores and higher level of participation than those who attended traditional instruction. This result is also inline with other studies in the literatures, which indicated that student's achievement in blended instruction was slightly better than traditional instruction [10], [28]-[30]. The term of achievement used in this study refers to the student's learning outcome for quizzes and assignments during the experimentation.

These findings encourage universities to promote learning environments that use blended learning approaches in their courses. Student-centered learning environment can be created because students in the blended courses are proven to be more active and more involvement in the learning activity. Other studies [31]-[33] are in agreement with this result.

\section{CONCLUSIONS}

This study showed that the implementation of the blended learning in Multimedia courses provides more benefits to 
students in terms of higher achievement and level of participations compared to the traditional face-to-face learning. In addition, students had been satisfied with the blended course and perceived positive attitudes towards the implementation of blended learning. These suggest that universities, teachers and instructors should be encouraged to support the implementation of this emerging blended learning instruction.

\section{REFERENCES}

[1] J. M. Spector et al., Handbook of Research on Educational Communications and Technology, New York, NY: Springer New York, 2014.

[2] D. Conrad, "E-learning and social change: An apparent contradiction," Perspectives on Higher Education in the Digital Age, pp. 21-33, New York: Nova Science Publishers, 2006.

[3] B. Khan, "Managing e-learning: Design, delivery, implementation and evaluation," Hershey, PA: Information Science Publishing, 2005.

[4] T. Urdan, and C. Weggen, Corporate e-Learning: Exploring a New Frontier, Berwyn, Penn.: Hambrecht \& Co, 2000.

[5] M. J. Rosenberg, E-Learning: Strategies for Delivering Knowledge in the Digital Age, New York, NY, USA: McGraw-Hill, Inc., 2002.

[6] A. Al-Azawei, A. Al-Bermani, and K. Lundqvist, "Evaluating the effect of Arabic engineering students' learning styles in blended programming courses," Journal of Information Technology Education: Research, vol. 15, pp. 109-130, 2016.

[7] I. Clark, and P. James, "Blended learning: An approach to delivering science courses on-line," in Proc. the Blended Learning in Science Teaching and Learning Symposium, pp. 19-24, The University of Sydney: UniServe Science, 2005.

[8] J.-C. Yen and C.-Y. Lee, "Exploring problem solving patterns and their impact on learning achievement in a blended learning environment," Computers \& Education, vol. 56, no. 1, pp. 138-145, 2011.

[9] D. R. Garrison and H. Kanuka, "Blended learning: Uncovering transformative potential in higher education," The Internet and Higher Education, vol. 7, no. 2, pp. 95-105, 2004.

[10] N. Vernadakis, M. Giannousi, V. Derri, M. Michalopoulos, and E. Kioumourtzoglou, "The impact of blended and traditional instruction in students' performance," Procedia Technology, vol. 1, pp. 439-443, 2012.

[11] C. R. Graham, "Blended learning systems: Definitions, current trends and future directions," The Handbook of Blended Learning: Global Perspectives, Local Designs, pp. 3-21, San Francisco: Pfeiffer, 2006.

[12] J. J. Wong, "Traditional versus hybrid courses," International Journal of Learning, vol. 13, no. 8, pp. 163-170, 2006.

[13] I. E. Allen, J. Seaman, and R. Garrett, Blending in: The extent and Promise of Blended Education in the United States, Needham, MA: The Sloan Consortium, 2007.

[14] A. G. Picciano, "Blended learning: Implications for growth and access," Journal of Asynchronous Learning Networks, vol. 10, no. 3 , pp. 95-102, 2006.

[15] D. R. Garrison and N. Vaughan, Blended Learning in Higher Education: Framework, Principles and Guidelines, San Francisco: Jossey-Bass, 2008.

[16] M. Kaur, "Blended learning - Its challenges and future," Procedia Social and Behavioral Sciences, vol. 93, no. 21, pp. 612-617, 2013.

[17] S. Laster, G. Otte, A. Picciano, and S. Sorg, "Redefining blended learning," Presentation at the 2005 Sloan-C Workshop on Blended Learning, Chicago, IL, 2005.

[18] C. Chen and K. Jones, "Blended learning vs. Traditional classroom settings: Assessing effectiveness and student perceptions in an MBA accounting course," The Journal of Educators Online, vol. 4, no. 1, pp. $1-15,2007$.

[19] B. Melton, H. Graf, and J. Chopak-Foss, "Achievement and satisfaction in blended learning versus traditional general health course designs," International Journal for the Scholarship of Teaching and Learning, vol. 3, no. 1, pp. 1-13, 2009.
[20] K. Carmody and Z. Berge, "Elemental analysis of the online learning experience," International Journal of Education and Development using Information and Communication Technology, vol. 1, no. 3, pp. 108-119, 2005.

[21] J. Davies and M. Graff, "Performance in e-learning: Online participation and student grades," British Journal of Educational Technology, vol. 36, no. 4, pp. 657-663, 2005.

[22] J. Gallini and D. Barron, "Participants' perceptions of web-infused environments: A survey of teaching beliefs, learning approaches, and communication," Journal of Research on Technology in Education, vol. 34, no. 2, pp. 139-156, 2002.

[23] H. D. Surjono, "The effects of multimedia and learning style on student achievement in online electronics course," Turkish Online Journal of Educational Technology-TOJET, vol. 14, no. 1, pp. 116-122, 2015.

[24] H. I. Akyüz and S. Samsa, "The effects of blended learning environment on the critical thinking skills of students," Procedia Social and Behavioral Sciences, vol. 1, no. 1, pp. 1744-1748, 2009.

[25] G. Hughes, "Using blended learning to increase learner support and improve retention," Teaching in Higher Education, vol. 12, no. 3, pp. 349-363, 2007.

[26] V. Woltering, A. Herrler, K. Spitzer, and C. Spreckelsen, "Blended learning positively affects students' satisfaction and the role of the tutor in the problem-based learning process: Results of a mixed-method evaluation," Advances in Health Sciences Education, vol. 14, no. 5, pp. 725-738, 2009.

[27] B. Güzer and H. Caner, "The past, present and future of blended learning: an in depth analy-sis of literature," Procedia-Social and Behavioral Sciences, vol. 116, pp. 4596-4603, 2014.

[28] H. Atan, Z. Rahman, and R. Idrus, "Characteristics of the web based learning environment in distance education: Students' perceptions of their learning needs," Educational Media International, vol. 41, no. 2, pp. 103-110, 2004.

[29] H. El-Deghaidy and A. Nouby, "Effectiveness of a blended e-learning cooperative approach in an Egyptian teacher education programme," Computers \& Education, vol. 5, no. 3, pp. 988-1006, 2008.

[30] P. Zubas, C. Heiss, and M. Pedersen, "Comparing the effectiveness of a supplemental online tutorial to traditional instruction with nutritional science students," Journal of Interactive Online Learning, vol. 5, no. 1, pp. 75-81, 2006.

[31] V. Chandra and D. L. Fisher, "Students' perceptions of a blended web-based learning environment," Learning Environment Research, vol. 12, pp. 31-44, 2009.

[32] H.-J. So and T. A. Brush, "Students perceptions of collaborative learning, social presence and satisfaction in a blended learning environment: Relationships and critical factors," Computers \& Education, vol. 51, no. 1, pp. 318-336, 2008.

[33] C. C. Chen and K. T. Jones, "Blended learning vs. traditional classroom settings: Assessing effectiveness and student perceptions in an accounting course," The Journal of Educators Online, vol. 4, no. 1, pp. $1-15$.

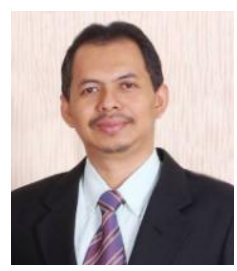

Herman Dwi Surjono is a professor at the College of Engineering and the Graduate School of the Yogyakarta State University, Indonesia. He got his master degree from the Iowa State University in 1995. He received his Ph.D. in information technology in 2006 from Southern Cross University Australia.

$\mathrm{He}$ teaches both undergraduate and graduate students computer programming, e-learning, interactive multimedia, and digital media. His research area includes adaptive hypermedia, computer based learning, and e-learning. He has experiences in providing consulting and training and development of Moodle based e-learning. He has published articles and books related to e-learning and multimedia. His goal is to empower teachers to optimize the use of e-learning in schools.

Prof. Surjono is a head of Instructional Technology Department at the Graduate School of YSU. He is a Senior Member No: 80343064 International Association of Computer Science and Information Technology (IACSIT) since 2011. 